\title{
PLANT INVASIONS ACROSS DIFFERENT HABITAT TYPES AT FLORISTIC SURVEY
}

\author{
MYŚLIWY, M. \\ Department of Plant Taxonomy and Phytogeography, Faculty of Biology, University of Szczecin \\ Waska 13, 71-415 Szczecin, Poland \\ e-mail:nikabot@univ.szczecin.pl \\ (Received $19^{\text {th }}$ Aug 2013 ; accepted $22^{\text {nd }}$ July 2014)
}

\begin{abstract}
On the basis of detailed floristic survey the level of invasion in various EUNIS habitat types identified in NW Poland was assessed. In a data set of 2131 floristic lists the mean number and mean proportion of native species, archaeophytes and neophytes was calculated for each of 25 habitat types. Relationships between this three groups of species were analysed using Pearson correlation. A total of 840 vascular plant species, including 77 archaeophytes and 114 neophytes were recorded. The most invaded habitats were: arable land, fallows and field margins, trampled areas, gardens and parks, lines of trees, anthropogenic tall-forb stands (they contained on average $20-67 \%$ alien plants). Most of mean numbers and mean percentage numbers of both alien plants groups in particular habitat types were higher compared to the results obtained from phytosociological databases, therefore the level of invasion assessed on the basis of phytosociological data can be underestimated.
\end{abstract}

Keywords: alien species, archaeopytes, EUNIS, level of invasion, neophytes

\section{Introduction}

Enriching the existing vegetation of an area with geographically alien species is the most conspicuous anthropogenic effect on the flora. A particularly rapid increase in the intensity of alien plants expansion was observed in the recent centuries (Lambdon et al., 2008). It is widely recognized that the invasion of alien plants (sensu Pyšek et al., 2004) threats natural ecosystems, as well as human health and economy (Wade et al., 1997; Pimentel et al., 2005; Tokarska-Guzik et al., 2006; Hejda et al., 2009; Follak et al., 2013), therefore investigating the causes and mechanisms of biological invasions is one of the most urgent task of modern geobotany. A very important line of research tackles the extent of resistance of various habitats and plant communities to penetration of adventive species. Individual habitats vary considerably in their susceptibility to invasion (invasibility sensu Lonsdale, 1999; Richardson and Pyšek, 2006), as well as actual level of invasion (sensu Hierro et al., 2005), so reliable quantitative information is crucial for effective management and planning of invasive plant control, but studies providing solid quantitative data are still rather few (Pyšek et al., 1998; Chytrý et al., 2005; Vilà et al., 2007; Botta-Dukát, 2008; Sîrbu et al., 2012).

The most of analyses of the level of invasion in different habitats are based on phytosociological relevés, which were made with the purpose to study particular vegetation, not to study particular habitat. Examples using a systematic floristic study of the area are extremely rare (Pyšek et al., 2002; Jauni and Hyvönen, 2010). It would be interesting to compare the results obtained from systematic detailed floristic survey through the habitats with those from phytosociological databases. Studies of this type, carried out in an area under legal protection, with very few habitats altered by human activities, identify which less-disturbed, (semi-)natural habitats can be vulnerable to the 
spread of alien species. That is the reason why the present study was based on floristic research conducted in Barlinek-Gorzów Landscape Park (NW Poland).

The high quality assessment of particular species in the local and regional floras investigated with respect to their taxonomic identity, time of immigration and invasion status is crucial for comparative analyses (Pyšek et al., 2004). In recent floras alien plant species are classified according to their invasion status as casual or naturalized and according to their residence time into archaeophytes (species that arrived before AD 1500) and neophytes (species introduced after that date). The establishment and spread of naturalized neophytes in Poland is well documented (Tokarska-Guzik, 2005) and the list of archaeophytes is available (Zając, 1979), but a precise assignation of some species is still doubtful (Mirek et al., 2002).

The major aims of this work was (1) to assess the level of invasion in various habitat types of the studied area, expressed as the number of alien species they harbour and the proportion of aliens to the total number of species, and to compare it with other authors results obtained from phytosociological databases, (2) to provide the lists of archaeophytes and neophytes which occur in the broadest range of habitats, (3) to determine relationships between alien and native species across and within habitats.

\section{Material and methods}

\section{Study area}

Barlinek-Gorzów Landscape Park (BGLP) is located in the North-West of Poland, at $52^{\circ} 48^{\prime} \mathrm{N}-53^{\circ} 05^{\prime} \mathrm{N}$ and $15^{\circ} 08^{\prime} \mathrm{E}-15^{\circ} 26^{\prime} \mathrm{E}$. It encompasses a valuable, about 24000 ha, fragment of Pomeranian Lakelands. The greater part of this area is a sandy sandr varied with postglacial channels and peat basins, while its very northern part presents glacial forms connected with the southern range of the Pomerania phase of the Vistula glaciation (Kondracki, 2000). The frontal moraine features humus-rich podsols overlaying till clay as well as brown forest soils lined by heavy clay. The glacial outwash plain is covered mainly by podsols devoid of any clay lining (Mikołajski, 1966). This area is in the zone of influences of the oceanic climate. The mean annual air temperature is $8.1^{\circ} \mathrm{C}$. The mean annual precipitation sum is $500-600 \mathrm{~mm}$, with distinct decrease during summer months. The duration of the vegetation season ranges from 200 to 220 days (Koźmiński and Michalska, 2001).

Forests, covering about $80 \%$ of the Park's surface area, are the most important component of its natural world. The forests are mainly broadleaved deciduous forests (in particular acidophilous beech-oak forest, lowland forb-rich and acidophilous beech forests) as well as mixed broadleaved deciduous and coniferous forests. Coniferous forest, riparian woodlands and alder carrs are less common. Due to the human activity the tree stands are often dominated by the artificially introduced Pinus sylvestris. Important are also Fagus sylvatica subsp. sylvatica, Quercus robur and Q. petraea, followed by Carpinus betulus, Betula pendula, and the artificially introduced Picea abies. The study area is also characteristic for chains of post-glacial lakes with small rivers flowing through them. Compared to adjacent areas, the Park's natural environment is relatively weakly transformed due to the low intensity of urbanisation and industrialisation - the area lacks large urban centres, major roads and railway tracks. Anthropogenic pressure is basically limited to forest management, extensive agriculture on the northern part, and tourism. 


\section{Data collecting and statistical analyses}

The present study is based on the research on distribution and anthropogenic transformations of the BGLP vascular flora, carried out in 1998-2002 (Myśliwy, 2003). The Park area was divided into 271 quadrants (side length of $1 \mathrm{~km}$ ), which constitute a decimal resolution of the cartographic grid used in the "Distribution Atlas of Vascular Plants in Poland" (Zając, 1978); each quadrant was equivalent to a site. On average 7-8 floristic lists were obtained in each quadrant, with a due consideration to the full variety of habitats (plots 40-200 $\mathrm{m}^{2}$ ). Only vascular plants were recorded. On account of the application of a cartogram grid to systematic field surveys, the difference in the number of floristic lists in individual habitat types is more a result of habitat availability in an area than of inhomogeneity of survey coverage. The total number of 2131 floristic lists were analyzed in this study.

Classification of habitat types was based on the European Nature Information System (EUNIS) (Davies et al., 2004). Level 2 and Level 3 of the EUNIS hierarchy were used, from the version of classification available online from January 2013 (in one case Level 1 was accepted and in one case two habitat types at Level 3 were merged). Generally, the area was found to support 25 habitat types encompassing a full range from those little altered by anthropogenic influences to the strikingly anthropogenic ones, the latter being rather rare (Table 1). Number of lists assigned to particular habitats ranged from one to 479 (Table 2).

Each plant species from analysed floristic lists were classified into native, archaeophyte or neophyte, using studies of Zając (1979), Zając et al. (1998), Zając and Zając (2001), Mirek et al. (2002), Tokarska-Guzik (2005) and Tokarska-Guzik et al. (2012). The non-native plants were classified with respect to Western Pomerania as the area of reference, so species native to Poland but alien to NW Poland were treated as aliens. In case of species with doubtful status in the Polish or Pomeranian flora the following assignations were adopted: native species - Berteroa incana, Cirsium vulgare, Erysimum cheiranthoides, Geranium columbinum, Rumex thyrsiflorus, Teucrium scorodonia; neophytes - Oenothera biennis, Primula elatior, Viola odorata; archaeophytes - Anchusa officinalis, Geranium molle, Malva alcea, Silene latifolia subsp. alba, Misopates orontium, Pastinaca sativa. For each floristic list the number of species within each of above three categories was counted, as well as proportion of archaeophytes and neophytes from total number of species was calculated. The mean number and mean proportion of native species, archaeophytes and neophytes was then calculated for each habitat type. To check if the differences were statistical significant the non-parametric Kruskall-Wallis test of ranks was used. The proportion of floristic lists with at least one alien species and at least one neophyte was also calculated for each habitat type.

Relationships between native species, archaeophytes and neophytes across and within habitat types were analysed using Pearson correlation. The number of species within each species group and each floristic list was square-root transformed after adding 0.5 to each value. For the analyses across habitats averages of these transformed values were taken. All statistical analyses were performed using the STATISTICA 10 program (www.statsoft.com).

Names of vascular plant species follow Flora Europaea (Tutin et al., 1964-1980). 
Table 1. The list of EUNIS habitat types identified in the study area (NW Poland)

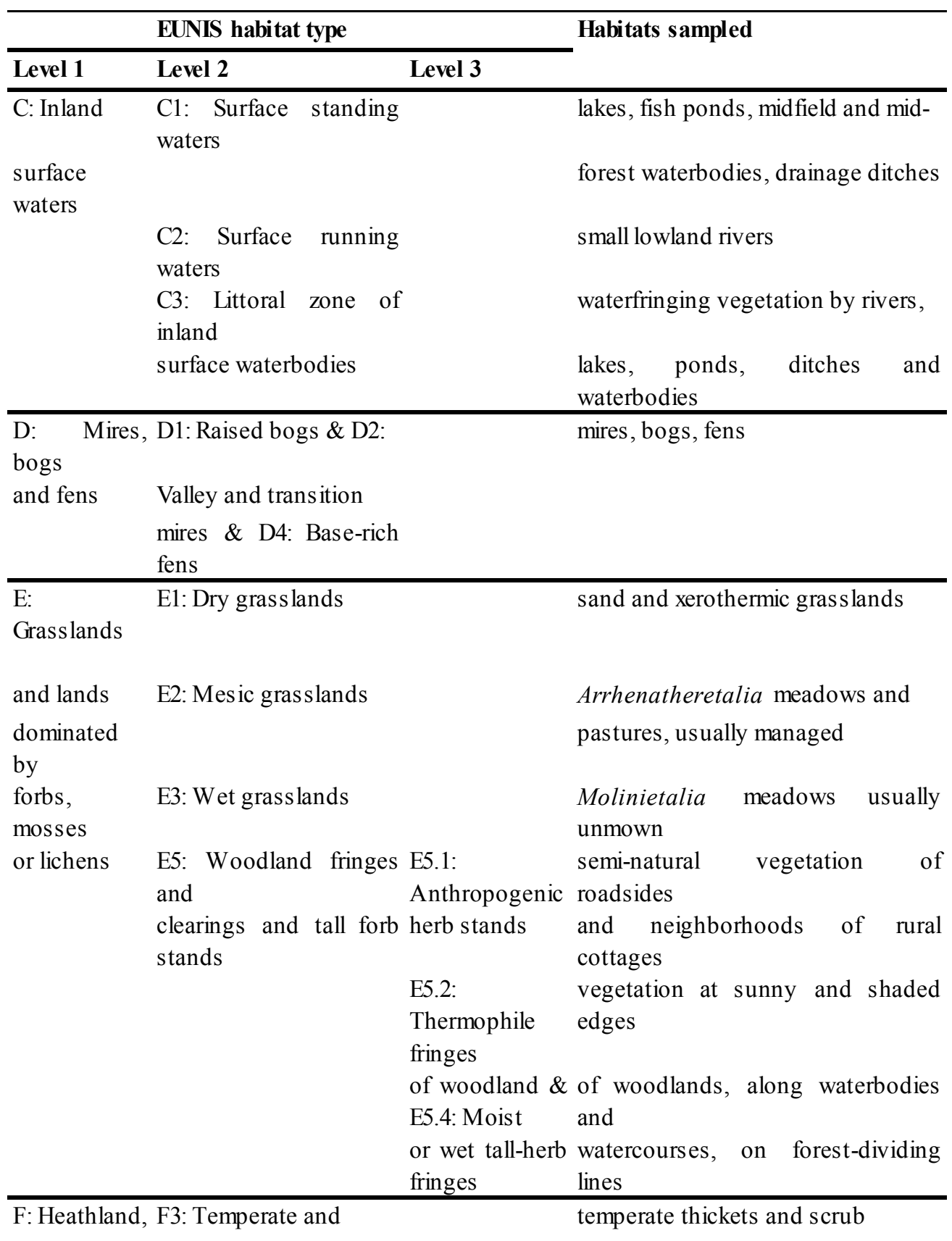

scrub and mediterranean scrub

tundra F9: Riverine and fen riverside, lakeside and fen scrub of scrubs

Salix and/or Alnus ssp.

FA: Hedgerows strips of shrubs within cultivated

land

or along roads

\begin{tabular}{lll}
\hline G: & G1: Broadleaved & $\begin{array}{l}\text { woodland, forest, } \\
\text { dominated }\end{array}$ \\
Woodland, & by broadleaved deciduous trees \\
forest and & deciduous woodland & by
\end{tabular}




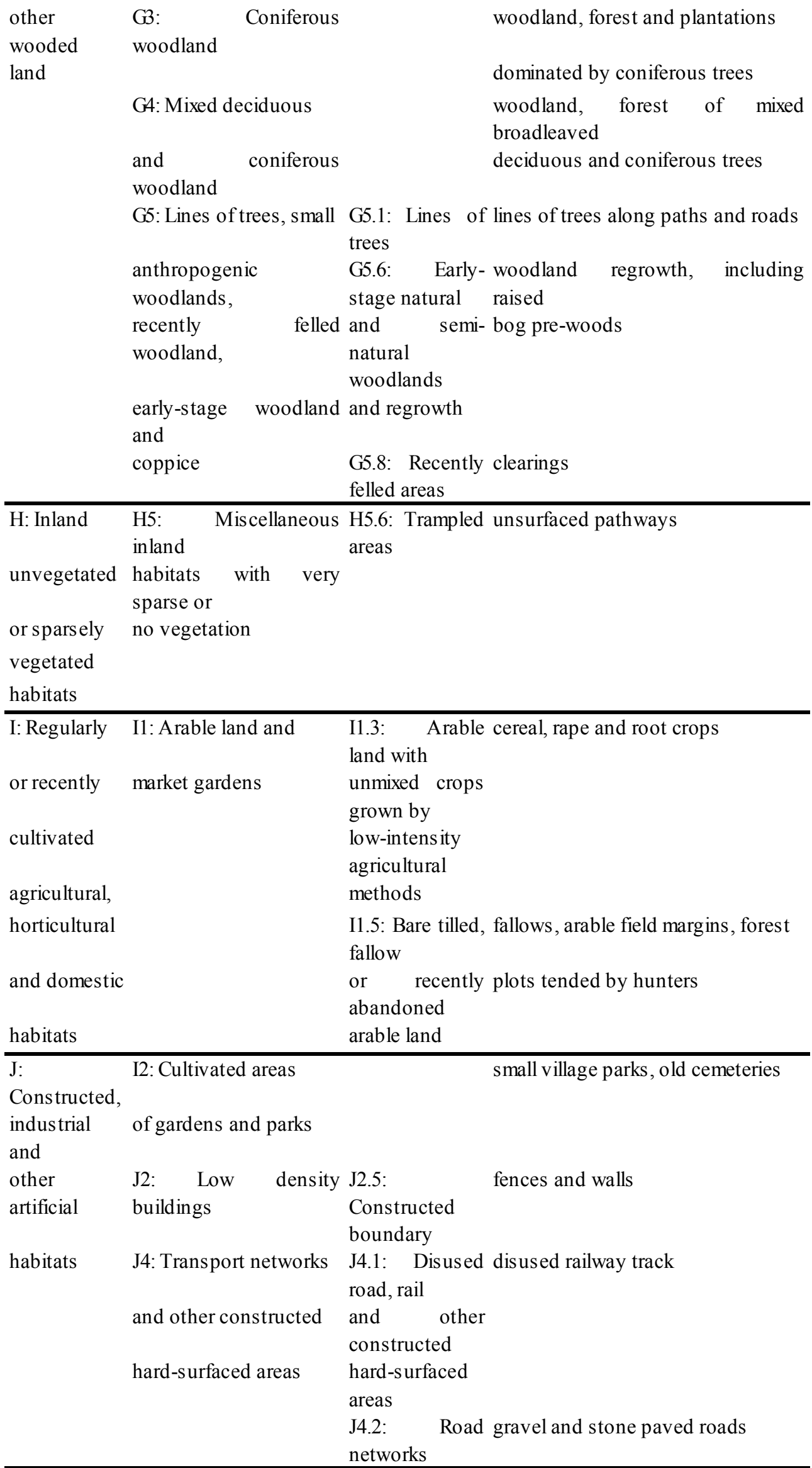


Table 2. Mean numbers of species in floristic lists assigned to particular habitat types

\begin{tabular}{|c|c|c|c|c|c|c|c|}
\hline \multirow[t]{2}{*}{ EUNICE $^{1}$ habitat type } & \multirow[t]{2}{*}{$\mathbf{n}^{2}$} & \multicolumn{3}{|c|}{$\begin{array}{l}\text { Mean No. } \\
\text { of species }\end{array}$} & \multicolumn{3}{|c|}{$\begin{array}{l}\text { Mean \% No. } \\
\text { of species }\end{array}$} \\
\hline & & $\mathbf{N a t}^{\mathbf{3}}$ & $\operatorname{Arch}^{4}$ & $\mathrm{Neo}^{5}$ & $\mathbf{N a t}^{3}$ & $\operatorname{Arch}^{4}$ & $\mathrm{Neo}^{5}$ \\
\hline C1 Standing waters & 80 & 4,5 & 0 & 0,1 & 97,4 & 0 & 2,6 \\
\hline C2 Running waters & 13 & 2,5 & 0 & 0,1 & 98,9 & 0 & 1,1 \\
\hline C3 Littoral zone & 119 & 11,3 & 0,1 & 0,2 & 98,6 & 0,3 & 1,2 \\
\hline D Mires, bogs, fens & 66 & 23 & 0,1 & 0,3 & 98,5 & 0,3 & 1,2 \\
\hline E1 Dry grasslands & 39 & 45,5 & 6,9 & 2,8 & 82,7 & 12,2 & 5,1 \\
\hline E2 Mesic grasslands & 35 & 37,9 & 4,6 & 1,4 & 86,9 & 9,9 & 3,1 \\
\hline $\begin{array}{l}\text { E3 Wet grasslands } \\
\text { E5.1 Anthropogenic tall-forb }\end{array}$ & 85 & 46,9 & 0,7 & 0,5 & 97,6 & 1,3 & 1,1 \\
\hline stands & 179 & 26,7 & 3,2 & 2,9 & 79,5 & 9,7 & 10,8 \\
\hline E5.2 \& E5.4 Woodland fringes & 479 & 18,8 & 0,7 & 1,1 & 91,1 & 2,9 & 6,1 \\
\hline F3: Temperate scrub & 9 & 29,3 & 0,8 & 2,7 & 88,8 & 2,2 & 9 \\
\hline F9: Riverine and fen scrubs & 22 & 24 & 0,2 & 0,6 & 96,7 & 0,6 & 2,7 \\
\hline FA: Hedgerows & 21 & 36,1 & 4,5 & 4,3 & 80,6 & 9,9 & 9,5 \\
\hline G1: Broadleaved woodland & 380 & 29,4 & 0,3 & 1,3 & 95,5 & 1 & 3,6 \\
\hline G3: Coniferous woodland & 189 & 21,1 & 0,2 & 1,1 & 93,7 & 0,8 & 5,5 \\
\hline G4: Mixed woodland & 220 & 23,4 & 0,2 & 1 & 95,2 & 0,8 & 4 \\
\hline G5.1: Lines of trees & 16 & 33,3 & 3,8 & 4 & 77,8 & 9,7 & 12,5 \\
\hline G5.6: Early-stage woodlands & 34 & 29,1 & 0,8 & 1,5 & 92,1 & 2,4 & 5,5 \\
\hline G5.8: Recently felled areas & 12 & 25,4 & 1,4 & 1,3 & 82,7 & 3,2 & 14,1 \\
\hline H5.6: Trampled areas & 26 & 10,7 & 2 & 1,3 & 76 & 13,2 & 10,8 \\
\hline I1.3: Arable land & 31 & 5,7 & 9,6 & 1 & 32,9 & 59,2 & 7,8 \\
\hline I1.5: Fallows, fields margins & 50 & 25,6 & 8,7 & 2,6 & 66,1 & 26,4 & 7,5 \\
\hline I2: Gardens and parks & 6 & 35 & 0,7 & 9 & 77,5 & 1,8 & 20,7 \\
\hline J2.5: Constructed boundaries & 1 & - & - & - & - & - & - \\
\hline J4.1: Disused rail & 5 & 31,4 & 1,2 & 1,2 & 93,1 & 3,8 & 3,1 \\
\hline J4.2: Road networks & 14 & 11,8 & 1,9 & 0,7 & 83,3 & 12,2 & 4,5 \\
\hline
\end{tabular}

${ }^{1}$ EUNIS habitat names are abbreviated: for full names see Table $1 ;{ }^{2} n:$ number of floristic lists; ${ }^{3}$ Nat: native species; ${ }^{4}$ Arch: archaeophytes; ${ }^{5}$ Neo: neophytes

\section{Results}

The data set of 2131 floristic lists contained 649 (77.3\%) native species, 77 (9.2\%) archaeophytes and 114 (13.6\%) neophytes (including 88 naturalized and 26 casual). The average proportion ( \pm standard deviation) of this three species groups in individual floristic list was $90.6 \pm 13.2 \%, 4.2 \pm 10.1 \%$ and $5.2 \pm 7.6 \%$ respectively. The total number (species pool) of archaeophytes and neophytes in particular habitats ranged in turn: 0-61 and 1-71.

The list of archaeophytes and kenophytes occurring in the highest number of habitats were compiled (Table 3). Among archaeophytes 19 species (24.7\%) may be considered as generalists (they occupied more then ten habitat types), while $38(49.4 \%)$ - as 
specialists (occurring in 1-5 habitats). In case of neophytes the group of specialists was composed of $77(67.4 \%)$ species, while only 15 neophytes $(13.2 \%)$ were generalists (all of them are naturalized species in Poland). The group of species, occurring in 6-10 habitat types were similar for archaeophytes and neophytes - $20(26.0 \%)$ and 22 $(19.3 \%)$ species respectively.

Table 3. Fifteen archaeophytes and neophytes with the broadest habitat range $(n=25)$. Species are ranked in decreasing order according to the number of EUNIS habitat types in which they were recorded

\begin{tabular}{|c|c|c|c|c|}
\hline Archaeophytes & $\begin{array}{cc}\begin{array}{c}\text { No. } \\
\text { habitats }\end{array} & \text { of } \\
\end{array}$ & Neophytes & $\begin{array}{c}\text { No. } \\
\text { habitats }\end{array}$ & of \\
\hline Myosotis arvensis & 18 & Conyza canadensis & 18 & \\
\hline $\begin{array}{l}\text { Fallopia convolvulus } \\
\text { Silene latifolia subsn }\end{array}$ & 17 & Impatiens parviflora & 18 & \\
\hline alba & 16 & Quercus rubra & 15 & \\
\hline Vicia tetrasperma & 16 & Epilobium adenocaulon & 14 & \\
\hline Capsella bursa-pastoris & 15 & Oxalis europaea & 14 & \\
\hline Matricaria perforata & 15 & Picea abies & 14 & \\
\hline Bromus sterilis & 14 & Robinia pseudacacia & 13 & \\
\hline Geranium pusillum & 14 & Senecio vernalis & 13 & \\
\hline Senecio vulgaris & 14 & Violoa odorata & 13 & \\
\hline Vicia hirsuta & 14 & Erigeron anпииs & 13 & \\
\hline Anagallis arvensis & 13 & Aesculus hippocastanum & 12 & \\
\hline Lactuca serriola & 13 & Juncus tenuis & 12 & \\
\hline Lamium purpureum & 13 & Prunus serotina & 12 & \\
\hline Viola arvensis & 13 & Pyrus communis & 12 & \\
\hline Ballota nigra & 12 & Solidago canadensis & 11 & \\
\hline
\end{tabular}

The proportion of floristic lists containing at least one alien species was very high for most of habitat types, the same was stated in case of neophytes (Fig. 1a, 1b). Considering the total number (species pool) of both alien groups in each habitat type greater differentiation between habitats was obtained (Fig. 2). When the habitat comparison was based on total number of occurrences (records) of alien species instead of total number of species - few habitats remained among the most invaded (Fig. 3).

The mean number of species per floristic list was the highest in grasslands, especially in dry (E1) and wet grasslands (E3), while the lowest - in waters $(\mathrm{C} 1, \mathrm{C} 2)$, followed by littoral zone (C3), trampled areas (H5.6) and road networks (J4.2). There were significant differences in number of native species, archaeophytes and neophytes per floristic list among habitats (Kruskall-Wallis test of rank, $H=699.7872$ for native species, $H=877.8600$ for archaeophytes, $H=465.2251$ for neophytes, $P<0.001$ ). Arable land (I1.3), fallows and field margins (I1.5), dry grasslands (E1), followed by mesic grasslands (E2) and hedgerows (FA) harbored the highest mean numbers of archaeophytes (Table 2). The highest mean numbers of neophytes were found in gardens and parks (I2), followed by hedgerows (FA), lines of trees (G5.1) and anthropogenic tall-forb stands (E5.1). Considering mean percentage number of alien species trampled areas (H5.6) were among five the most invaded habitats (Table 2). The lowest mean numbers and the lowest mean percentage numbers of aliens, both archaeophytes and neophytes, were detected in standing waters $(\mathrm{C} 1)$, running waters (C2), littoral zone (C3), mires, bogs and fens (D), riverine and fen scrubs (F9), and wet grasslands (E3). Archaeophytes were rare also in woodland habitats: in broadleaved 
(G1), coniferous (G3) and mixed woodland (G4), as well as in woodland fringes (E5.2 \& E.5.4). An unexpected result was that in road networks archaeophytes were approximately three times more often recorded then neophytes (Table 2).
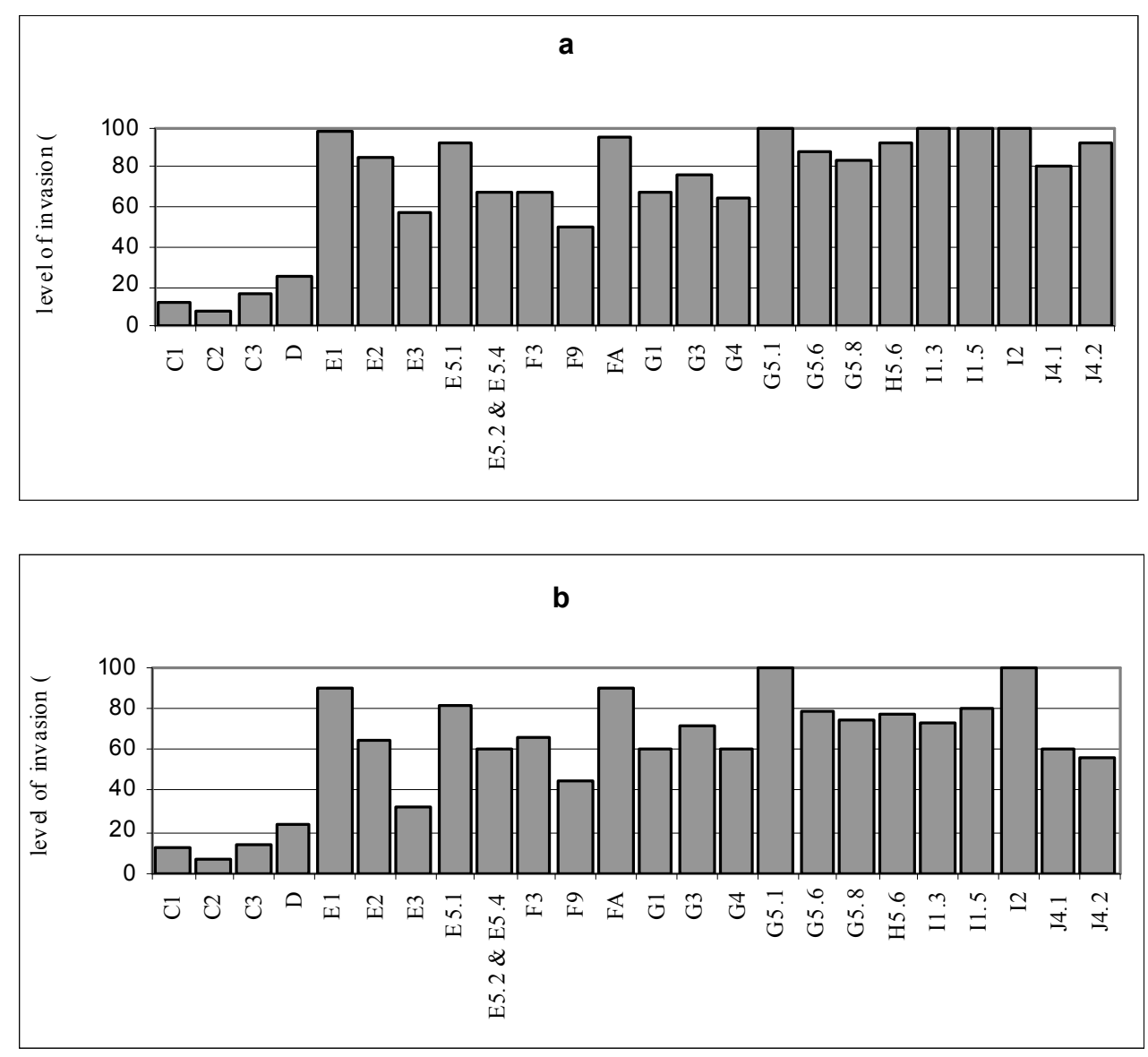

Figure 1. Level of invasion expressed by the proportion of floristic lists containing at least one alien species (a) or at least one neophyte (b). EUNIS habitat names are abbreviated: for full names see Table 1

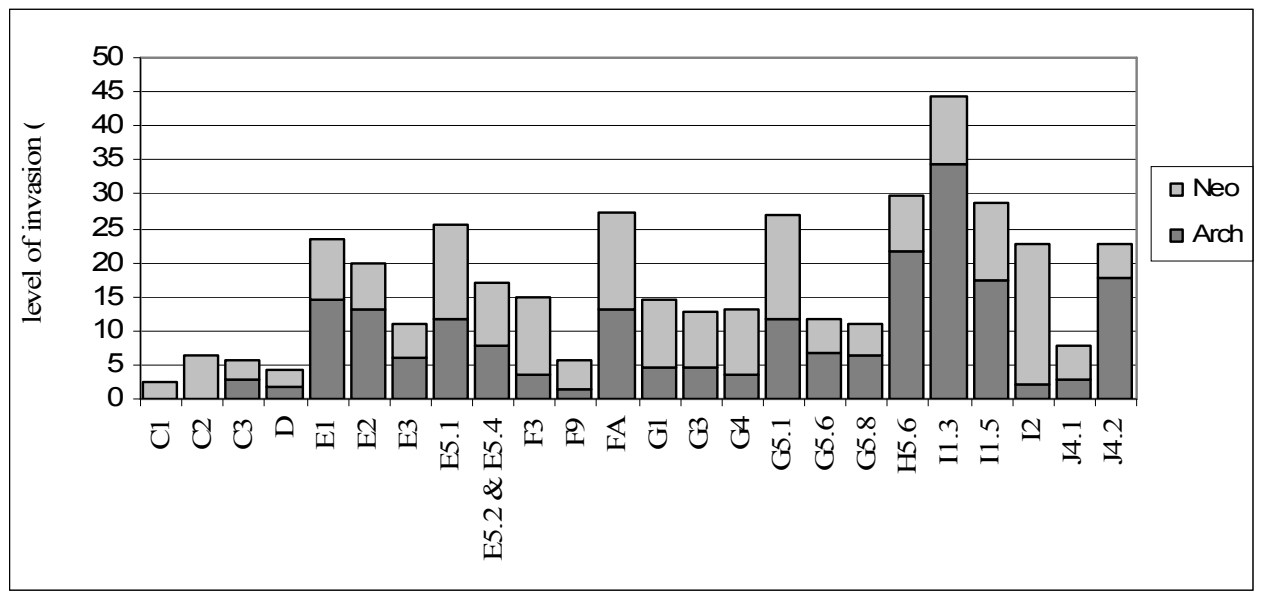

Figure 2. Level of invasion expressed by the proportion of alien species to the total number of species occurring in the habitat. EUNIS habitat names are abbreviated: for full names see

Table 1. Arch: archaeophytes, Neo: neophytes 


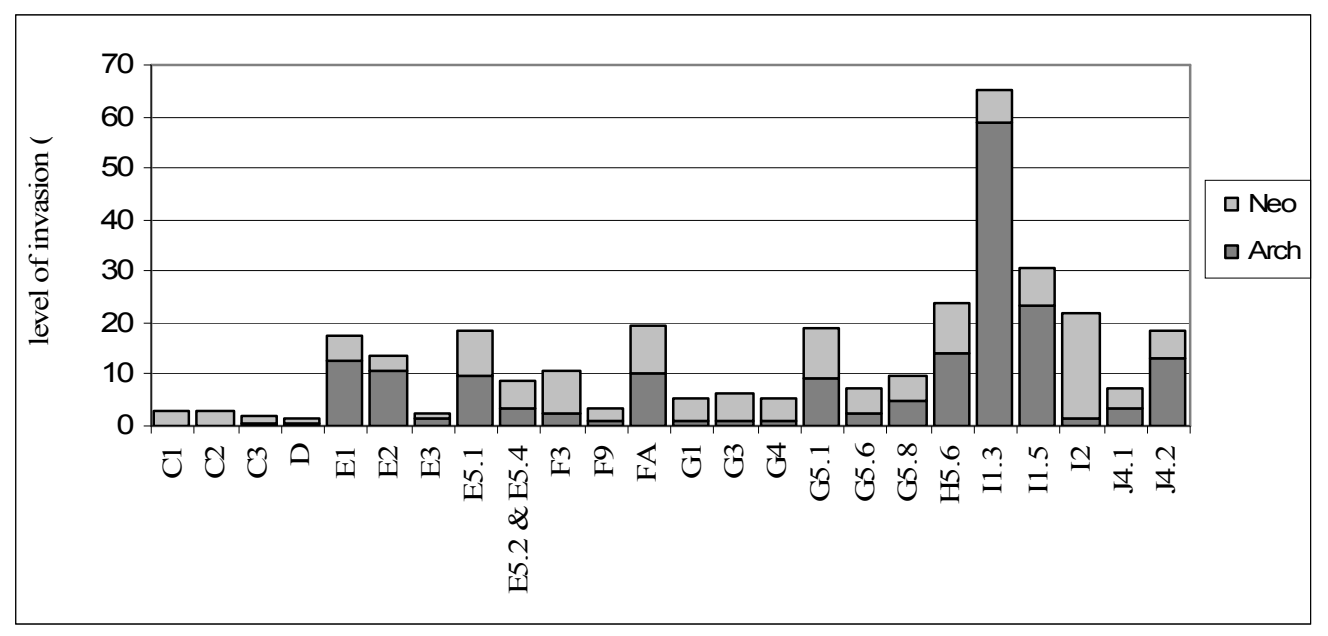

Figure 3. Level of invasion expressed by the proportion of records of alien species to the total number of records of species occurring in the habitat. EUNIS habitat names are abbreviated: for full names see Table 1. Arch: archaeophytes, Neo: neophytes

Table 1. Pearson correlation coefficients between the numbers of archaeophytes (Arch), neophytes (Neo) and native species (Nat) calculated within habitats. Square-root transformed (after adding 0.5) species numbers were used for calculation

\begin{tabular}{|c|c|c|c|c|c|c|c|}
\hline EUNICE $^{1}$ habitat type & $n^{2}$ & Arch vs. & Nat & Neo vs & Nat & Arch vs. & Neo \\
\hline $\mathrm{C} 1$ : Standing waters & 80 & $\begin{array}{l}\text { no } \\
\text { Arch } \\
\text { no }\end{array}$ & & n.s. & & no Arch & \\
\hline C2 Running waters & 13 & Arch & & n.s. & & no Arch & \\
\hline C3 Littoral zone & 119 & 0.483 & $* * *$ & 0.318 & $* * *$ & 0.325 & *** \\
\hline D Mires, bogs, fens & 66 & n.s. & & n.s. & & 0.311 & * \\
\hline E1 Dry grasslands & 39 & 0.630 & $* * *$ & 0.473 & $* *$ & 0.606 & $* * *$ \\
\hline E2 Mesic grasslands & 35 & n.s. & & n.s. & & 0.756 & *** \\
\hline $\begin{array}{l}\text { E3 Wet grasslands } \\
\text { E5.1 Anthropogenic tall-forb } \\
\text { stands }\end{array}$ & 179 & 0.627 & $\begin{array}{l}* * \\
* * *\end{array}$ & 0.534 & $* * *$ & 0.594 & $* * *$ \\
\hline E5.2 \& E5.4 Woodland fringes & 479 & 0.410 & $* * *$ & 0.393 & $* * *$ & 0.397 & *** \\
\hline F3: Temperate scrub & 9 & n.s. & & n.s. & & n.s. & \\
\hline F9: Riverine and fen scrubs & 22 & n.s. & & n.s. & & n.s. & \\
\hline FA: Hedgerows & 21 & 0.520 & * & 0.545 & $*$ & n.s. & \\
\hline G1: Broadleaved woodland & 380 & 0.319 & $* * *$ & 0.549 & $* * *$ & 0.306 & $* * *$ \\
\hline G3: Coniferous woodland & 189 & 0.512 & $* * *$ & 0.418 & $* * *$ & 0.327 & $* * *$ \\
\hline G4: Mixed woodland & 220 & 0.384 & $* * *$ & 0.489 & $* * *$ & 0.294 & $* * *$ \\
\hline G5.1: Lines of trees & 16 & 0.627 & $* *$ & 0.689 & $* *$ & 0.574 & * \\
\hline G5.6: Early-stage woodlands & 34 & 0.472 & $* *$ & 0.585 & $* * *$ & n.s. & \\
\hline G5.8: Recently felled areas & 12 & 0.624 & * & n.s. & & 0.675 & * \\
\hline H5.6: Trampled areas & 26 & n.s. & & n.s. & & n.s. & \\
\hline I1.3: Arable land & 31 & 0.623 & $* * *$ & 0.510 & $* *$ & n.s. & \\
\hline
\end{tabular}


I1.5: Fallows, fields margins

I2: Gardens and parks

J2.5: Constructed boundaries

J4.1: Disused rail

J4.2: Road networks

\begin{tabular}{llllll}
50 & 0.599 & $* * *$ & $0.557 * * *$ & 0.590 & $* * *$ \\
6 & n.s. & & $0.885 *$ & n.s. \\
1 & - & & - & & - \\
5 & n.s. & & n.s. & n.s. \\
14 & 0.708 & $* *$ & n.s. & n.s. \\
\hline
\end{tabular}

No. of positive significant correlations 15

13

12

No. of non significant correlations

7

11

10

${ }^{1}$ EUNIS habitat names are abbreviated: for full names see Table $1 ;{ }^{2} n:$ number of floristic lists; n.s.: non significant; no Arch: no occurrence of archaeophytes in the habitat; significance levels: $* * * P<$ $0.001 ; * * P<0.01 ; * P<0.05$

The analyses of relationship between the number of archaeophytes and native species performed within habitats revealed positive significant relationship in 15 habitats and non significant in seven (Table 4). No relationship between the number of species in both above groups was found in the analysis across different habitats $(r=0.162, P=$ $0.450)$. In case of relationship between the number of neophytes and native species the within-habitat analyses revealed 13 positive and 11 non significant correlations and significant but not very strong positive correlation in between-habitat analysis $(r=$ $0.503, P<0.05$; Fig. 4). The number of archaeophytes and neophytes is positively correlated in 12 habitats and non significant in ten (Table 4). Between-habitat analysis detected no relationship between the number of two latter species groups $(r=0.378, P=$ 0.069), but the significance was quite close to threshold value.

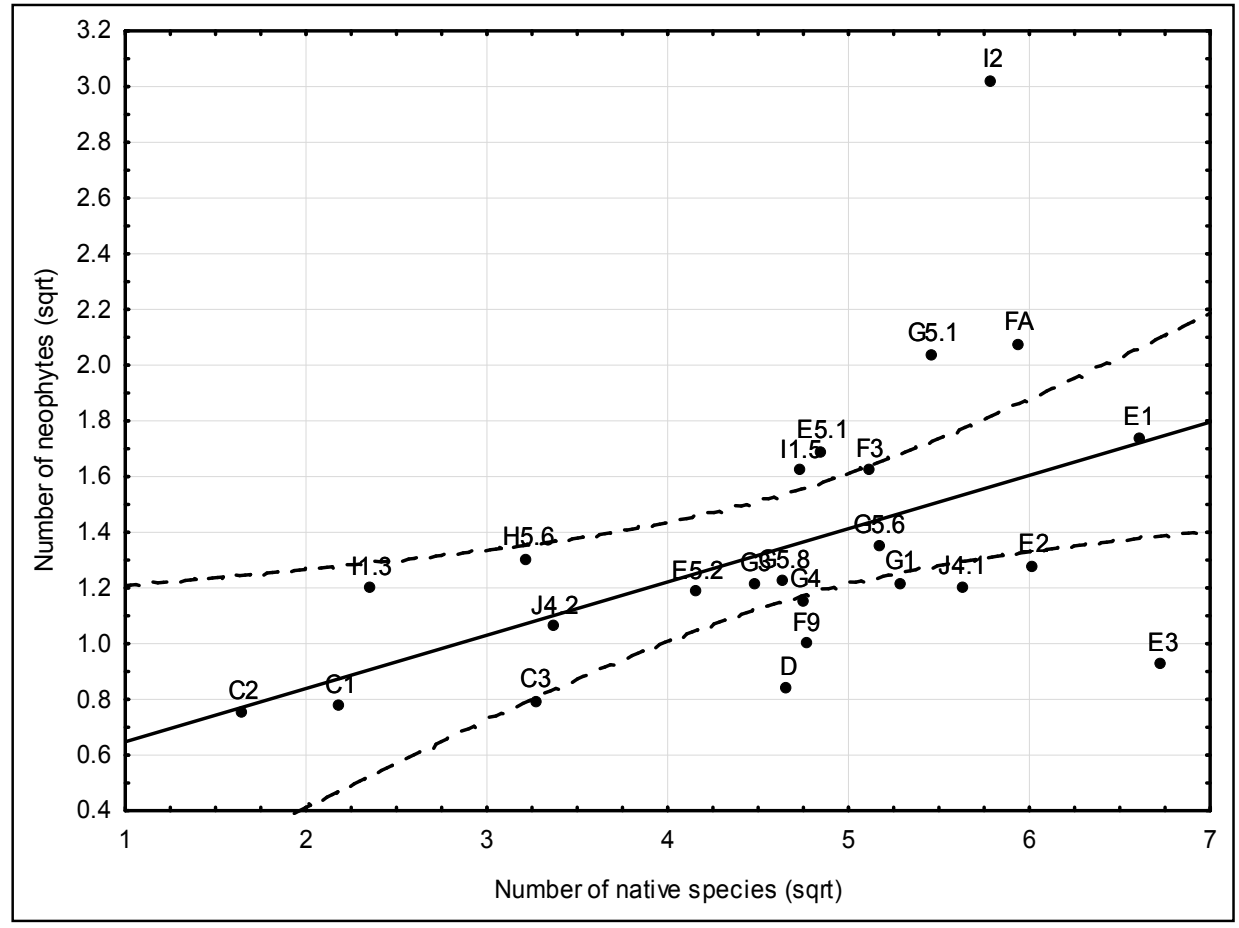

Figure 1. The relationship between the number of neophytes and native species. Averages from square-root transformed values were used for habitats, 95\% confidence interval is shown ( $r=$ 0.5, $P<0.05)$. EUNIS habitat names are abbreviated: for full names see Table 1 


\section{Discussion}

The vascular flora of Poland is estimated to contain 3476 species, including 2537 native species (73.0\%) and 939 aliens (157 archaeophytes - 4.5\%, 764 neophytes $22.0 \%$, further divided into two groups: established -370 species, and casual -394 species, and 18 species of uncertain status in Poland - 0.5\%) (Tokarska-Guzik et al., 2012). In the area of BGLP 24.2\% species of the entire Polish vascular flora were present (the proportion would be slightly higher if extinct and probably extinct species in the study area were included; compare Myśliwy, 2008a, 2010; Myśliwy and Bosiacka, 2009). Corresponding proportion for alien plants is $20.3 \%$, which shows that obtained data is representative and makes it possible to analyze the local pattern of plant invasions. The fraction of archaeophytes invading BGLP (49.0\%) is much higher compared to neophytes (14.9\%). The same was detected also in Czech nature reserves (Pyšek et al., 2002).

Although the group of neophytes makes up $20.0 \%$ of the flora of Poland, it amounts $5.2 \%$ of the species found in an average floristic list (plot), exceeds $10 \%$ in anthropogenic tall-forb stands, trampled areas, lines of trees and recently felled areas, and only in case of gardens and parks reaches $20.7 \%$. This contrast is mainly due to rare casual species, what pointed out e.g. Chytrý et al. (2005). Indeed in the data set used in this study neophytes were over-represented among very rare (1-3 sites of a total 271) and rare (4-8 sites) species (together they constitute $61.4 \%$ of all neophytes recorded). Very common (136-202 sites) and common (68-135 sites) neophytes were as follow: Picea abies, Juncus tenuis, Impatiens parviflora, Conyza canadensis, Oxalis europaea and Prunus serotina. The archaeophyte most common in the study area was Fallopia convolvulus, followed by Capsella bursa-pastoris, Silene latifolia subsp. alba, Matricaria perforata and Lamium purpureum. However very rare and rare archaeophytes constitute only $35.1 \%$ of all archaeophytes recorded in BGLP, so the rest of them are more frequent in the study area. This is in line with the proportion of archaeophytes in floristic lists $(4.2 \%)$, which is similar to their proportion in the total flora of the country (4.5\%). The same pattern of alien species frequency was detected in other neighboring landscape parks in Poland (Stępień, 2008, 2009), and it can be explained with the duration of their spreading over the territory and colonizing different habitats, which is clearly longer for archaeophytes (Chytrý at al., 2005; Pyšek et al., 2005; Richardson and Pyšek, 2006; Jauni and Hyvönen, 2010).

It must be underlined that most of mean numbers of archaeophytes and neophytes, as well as their mean percentage numbers obtained in this study were clearly higher compared to the results obtained from phytosociological databases (e.g. Chytrý et al., 2005, 2008; Vilà et al., 2007). This might be caused by the tendency to place phytosociological plots in sites with a high probability of including presumed diagnostic species (Chytrý, 2001) and to omit ecotones and disturbed, untypical phytocoenoses by phytosociologists. Such homogeneous stands of vegetation are probably less invaded, while ecotonal sites can be important habitats of some alien species. Therefore species lists obtained from heterogeneous plots are more complete then phytosociological relevés and give more reliable picture of pattern of plant invasions. The difference in the results would probably be higher if the number of analyzed floristic lists would be larger, comparable to phytosocjological databases, because as it was shown by Sîrbu et al. (2012), the number of relevés per habitat type significantly influences the probability to detect neophytes in a given habitat. In the data set used in this study there were also higher proportion of alien species, both archaeophytes and neophytes, with the broadest 
habitat range (compare Chytrý et al., 2005), and the higher proportion of lists containing at least one alien (neophyte) species (compare Sîrbu et al., 2012), probably as a consequence of sampling method. The level of invasion assessed on the basis of phytosociological data can be underestimated.

It was confirmed in this study that the most invaded habitats are those nutrient-rich and with frequent disturbances, both anthropogenic and natural, while by contrast nutrient-poor habitats, not affected by man are usually invaded to a lesser degree (Rejmánek, 1989; Deutschewitz et al., 2003; Chytrý et al., 2005, 2008, 2009; TokarskaGuzik, 2005; Vilà et al., 2007; Sîrbu et al., 2012). Moreover archaeophytes and neophytes have different habitat affinities, which reflects their history of invasion and their ecology in the native range (Pyšek et al., 2005; Richardson and Pyšek, 2006). Archaeophytes tend to be over-represented in arable land, because their spread was caused by agricultural activities (Zając, 1979). Their affinity to dry and mesic grasslands can be explained by their origin from open grasslands and therophytic habitats of southern Europe and Near East - about $60 \%$ of archaeophytes recorded in BGLP are of Mediterranean, Mediterraneo-Irano-Turanian and Irano-Turanian origin (Myśliwy, 2008a). Some of them are even diagnostic species of xerothermic communities in Poland (Myśliwy, 2010). On the other hand some dry grasslands have been ploughed in the past and nowadays they often neighbor arable fields, which influence their species composition (Botta-Dukát, 2008). The invasion of neophytes is connected with urban and transport development, and human population density play a significant role in recent alien invasions (McKinney, 2002; Pyšek et al., 2002; Pino et al., 2005; Tokarska-Guzik, 2005), so neophytes are over-represented in ruderal vegetation associated with human settlements. Due to their origin from temperate forests of North America and Eastern Asia in their secondary range neophytes are often components of woodlands and wet habitats (Chytrý et al., 2005, 2008; Botta-Dukát, 2008; Sirbu et al., 2012). Fragmentation of forest complexes by many kilometers of roads and paths facilitates non-intentional introduction of alien species (Trombulak and Frissel, 2000; Watkins et al., 2003). Fortunately the studied area is crossed by very few paved roads which could act as corridors for aliens to spread into natural communities. Instead, in commercially managed forests, the network of forest dividing-lines have been added, but their influence on forest interior's flora is moderate, in contrast to typical forest roads (Myśliwy, 2008b). Planting of trees originating both from other continents (particularly North-American) and from elsewhere in Poland (larch and spruce beyond their natural ranges) is an example of intentional introduction. Inappropriate forest management conducted with the direct introduction of alien species shouldn't be permitted and the principles of environmentally-friendly forestry practices should be observed.

On the example of Asteraceae family Jackowiak (1999) analysed the possibilities and limitations in prognosis of further expansion of alien plants and came to the conclusion that the exchange of the flora between various regions of the world has not been completed yet. All alien plants introduced to new areas should be assessed for their potential to escape, naturalize and cause damage. Some of them have the capacity to become invasive and these deserve very close attention (Kowarik, 1995; Wade, 1997; Starfinger, 1998; Pyšek et al., 2004). 


\section{REFERENCES}

[1] Botta-Dukát, Z. (2008): Invasion of alien species to Hungarian (semi-)natural habitats. Acta Botanica Hungarica 50 (Suppl): 219-227.

[2] Chytrý, M. (2001): Phytosociological data give biased estimates of species richness. Journal of Vegetation Science 12: 439-446.

[3] Chytrý, M., Maskell, L.C., Pino, J., Pyšek, P., Vilà, M., Font, X., Smart, S.M. (2008): Habitat invasions by alien plants: a quantitative comparison among Mediterranean, subcontinental and oceanic regions of Europe. - Journal of Applied Ecology 45: 448-458.

[4] Chytrý, M., Pyšek, P., Tichý, L., Knollová, I., Danihelka, J. (2005): Invasions by alien plants in the Czech Republic: a quantitative assessment across habitats. - Preslia 77: 339354.

[5] Chytrý, M., Pyšek, P., Wild, J., Pino, J., Maskell, L.C., Vilà, M. (2009): European map of alien plant invasions based on the quantitative assessment across habitats. - Diversity and Distributions 15: 98-107.

[6] Davies, C.E., Moss, D., Hill, M.O. (2004): EUNIS habitat classification revised 2004. European Environment Agency, European Topic Centre on Nature Protection and Biodiversity, Paris.

[7] Deutschewitz, K., Lausch, A., Kühn, I., Klotz, S. (2003): Native and alien plant species richness in relation to spatial heterogeneity on a regional scale in Germany. - Global Ecology \& Biogeography 12: 299-311.

[8] Follak, S., Dullinger, S., Kleinbauer, I., Moser, D., Essl, F. (2013): Invasion dynamics of three allergenic invasive Asteraceae (Ambrosia trifida, Artemisia annua, Iva xanthiifolia) in central and eastern Europe. - Preslia 85: 41-61.

[9] Hejda, M., Pyšek, P., Jarošik, V. (2009): Impact of invasive plants on the species richness, diversity and composition of invaded communities. - Journal of Ecology 97: 393-403.

[10] Hierro, J., Maron, J.L., Callaway, R.M. (2005): A biogeographical approach to plant invasions: the importance of studying exotics in their introduced and native range. Journal of Ecology 93: 5-15.

[11] Jackowiak, B. (1999): Modele ekspansji roślin synantropijnych i transgenicznych. Phytocoenosis 11 (N.S.), Seminarium Geobotanicum 6: 3-16.

[12] Jauni, M., Hyvönen, T. (2010): Invasion level of alien plants in semi-natural agricultural habitats in boreal region. - Agriculture, Ecosystems and Environment 138: 109-115.

[13] Kondracki, J. (2000): Geografia regionalna Polski. - Wydawnictwo Naukowe PWN, Warszawa.

[14] Kowarik, I. (1995): Time lags in biological invasions with regard to the success and failure of alien species. - In: Pyšek, P., Prach, K., Rejmánek, M., Wade, M. (eds.): Plant Invasions: general aspects and special problems: 15-38. SPB Academic Publishing, Amsterdam.

[15] Koźmiński, C., Michalska, B. (eds.) (2001): Atlas of climatic risk to crop cultivation in Poland. - Akademia Rolnicza w Szczecinie, Uniwersytet Szczeciński, Szczecin.

[16] Lambdon, P.W., Pyšek, P., Basnou, C., Hejda, M., Arianoutsou, M., Essl, F., Jarošik, V., Pergl, J., Winter, M., Anastasiu, P., Andriopoulos, P., Bazos, I., Brundu, G., CelestiGrapow, L., Chassot, P., Delipetrou, P., Josefsson, M., Kark, S., Klotz, S., Kokkoris, Y., Kühn, I., Marchante, H., Perglová, I., Pino, J., Vilà, M., Zikos, A., Roy, D., Hulme, P.E. (2008): Alien flora of Europe: species diversity, temporal trends, geographical patterns and research needs. - Preslia 80, 2: 101-149.

[17] Lonsdale, W.M. (1999): Global patterns of plant invasions and the concept of invasibility. - Ecology 80: 1522-1536.

[18] McKinney, M.L. (2002): Influence of settlement time, human population, park shape and age, visitation and roads on the number of alien plant species in protected areas in the USA. - Diversity and Distributions 8: 311-318. 
[19] Mikołajski, J. (1966): Geografia województwa szczecińskiego. - Szczecińskie Towarzystwo Naukowe 11: 1-156, Szczecin.

[20] Mirek, Z., Piękoś-Mirkowa, A., Zając, A., Zając, M. (2002): Flowering Plants and Pteridophytes of Poland. A checklist. - W. Szafer Institute of Botany, Polish Academy of Sciences, Cracow.

[21] Myśliwy, M. (2003): Flora roślin naczyniowych Barlinecko-Gorzowskiego Parku Krajobrazowego w warunkach antropogenicznych przemian środowiska przyrodniczego. - Ph.D. Dissertation, Department of Plant Taxonomy and Phytogeography, University of Szczecin.

[22] Myśliwy, M. (2008a): Archaeophytes in vascular flora of Barlinek-Gorzów Landscape Park (NW Poland): distribution, habitat preferences, threats. - Natura Montenegrina 7, 2: 217-230.

[23] Myśliwy, M. (2008b): Vascular plants of forest dividing-lines, analyzed in respect of forest complex synanthropisation. - Biodiversity: Research and Conservation 9-10: 6371.

[24] Myśliwy, M. (2010): Dynamics of xerothermic plant species in the upper River Płonia valley (NW Poland). - Natura Montenegrina 9, 3: 389-401.

[25] Myśliwy, M., Bosiacka, B. (2009): Disappearance of the Molinio-Arrhenatheretea meadows diagnostic species in the upper Płonia River Valley (NW Poland). - Polish Journal of Environmental Studies 18, 3: 513-519.

[26] Pimentel, D., Zuniga, R., Morrison, D. (2005): Update on the environmental and economic costs associated with alien-invasive species in the United States. - Ecological Economics 52: 273-288.

[27] Pino, J., Font, X., Carbó, J., Jové, M., Pallarès, L. (2005): Large-scale correlates of alien plant invasion in Catalonia (NE of Spain). - Biological Conservation 122: 339-350.

[28] Pyšek, P., Jarošík, V., Kučera, T. (2002): Patterns of invasion in temperate nature reserves. - Biological Conservation 104: 13-24.

[29] Pyšek, P., Jarošík, V., Chytrý, M., Kropáč, Z., Tichý, L., Wild, J. (2005): Alien plants in temperate weed communities: prehistoric and recent occupy different habitats. - Ecology 86: 772-785.

[30] Pyšek, P., Prach, K., Mandák, B. (1998): Invasions of alien plants into habitats of Central European landscape: an historical pattern. - In: Starfinger, U., Edwards, K., Kowarik, I., Williamson, M. (eds.): Plant Invasions: ecological mechanisms and human responses: 2332. Backhuys Publishers, Leiden.

[31] Pyšek, P., Richardson, D.M., Rejmánek, M., Webster, G.L., Williamson, M., Kirschner, J. (2004): Alien plants in checklists and floras: towards better communication between taxonomists and ecologists. - Taxon 53, 1: 131-143.

[32] Rejmánek, M. (1989): Invasibility of plant communities. - In: Drake, J.A., Mooney, H.A., di Castri, F., Groves, R.H., Kruger, F.J., Rejmánek, M., Williamson, M. (eds.): Biological Invasions: a global perspective: 369-388. John Wiley and Sons, Chichester.

[33] Richardson, D.M., Pyšek, P. (2006): Plant invasions: merging the concepts of species invasiveness and community invasibility. - Progress in Physical Geography 30, 3: 409431.

[34] Sîrbu, C., Oprea, A., Samuil, C., Tănase, C. (2012): Neophyte invasion in Moldavia (Eastern Romania) in different habitat types. - Folia Geobotanica 47: 215-229.

[35] Starfinger, U. (1998): On success in plant invasions. - In: Starfinger, U., Edwards, K., Kowarik, I., Williamson, M. (eds.): Plant Invasions: ecological mechanisms and human responses: 33-42. Backhuys Publishers, Leiden.

[36] Stępien, E. (2008): The characteristic of the archaeophytes appearing in the area of the Cedyński Landscape Park (NW Poland) - distribution, habitat conditions, the degree of naturalization and present threats. - Natura Montenegrina 7, 2: 309-323. 
[37] Stępień, E. (2009): Kenophytes in the Cedynia Landscape Park. - In: Holeksa, J., Babczyńska-Sendek, B., Wika, S. (eds.): The role of geobotany in biodiversity conservation: 309-317. University of Silesia, Katowice.

[38] Tokarska-Guzik, B. (2005): The establishment and spread of alien plant species (kenophytes) in the flora of Poland. - Wydawnictwo Uniwersytetu Śląskiego, Katowice.

[39] Tokarska-Guzik, B., Bzdęga, K., Knapik, D., Jenczała, G. (2006): Changes in plant species richness in some riparian plant communities as a result of their colonisation by taxa of Reynoutria (Fallopia). - Biodiversity: Research and Conservation 1-2: 123-130.

[40] Tokarska-Guzik, B., Dajdok, Z., Zając, M., Zając, A., Urbisz, A., Danielewicz, W., Hołdyński, C. (2012): Rośliny obcego pochodzenia w Polsce ze szczególnym uwzględnieniem gatunków inwazyjnych [Alien plants in Poland with particular reference to ivasive species]. - Generalna Dyrekcja Ochrony Środowiska, Warszawa. [In Polish with English summary].

[41] Trombulak, S.C., Frissel, C.A. (2000): Review of ecological effects of roads on terrestrial and aquatic communities. - Conservation Biology 14, 1: 18-30.

[42] Tutin, T.G., Heywood, V.H., Burges, N.A., Moore, D.M., Valentine, D.H., Walters, S.M., Webb, D.A. (eds.) (1964-1980): Flora Europaea. Vol. 1-5. - Cambridge University, Cambridge.

[43] Vilà, M., Pino, J., Font, X. (2007): Regional assessment of plant invasions across different habitat types. - Journal of Vegetation Science 18: 35-42.

[44] Wade, M. (1997): Predicting plant invasions: making a start. - In: Brock, J.H., Wade, M., Pyšek, P., Green, D. (eds.): Plant Invasions: studies from North America and Europe: 118. Backhuys Publishers, Leiden.

[45] Wade, M., Darby, E.J., Courtney, A.D., Caffrey, J.M. (1997): Heracleum mantegazzianum: a problem for river managers in the Republic of Ireland and the United Kingdom. - In: Brock, J.H., Wade, M., Pyšek, P., Green, D. (eds.): Plant Invasions: studies from North America and Europe: 139-151. Backhuys Publishers, Leiden.

[46] Watkins, R.Z., Chen, J., Pickens, J., Brosofske, K.D. (2003): Effects of forest roads on understory plants in a managed hardwood Landscape. - Conservation Biology 17, 2: 411419.

[47] Zając, A. (1978): Atlas of distribution of vascular plants in Poland. - Taxon 27: 481-484.

[48] Zając, A. (1979): Pochodzenie archeofitów występujących w Polsce [The origin of the archaeophytes occurring in Poland]. - Rozprawy habilitacyjne UJ 29: 1-213. [In Polish with English summary].

[49] Zając, A., Zając, M. (eds.) (2001): Distribution atlas of vascular plants of Poland. Laboratory of Computer Chorology, Institute of Botany, Jagiellonian University, Cracow.

[50] Zając, A., Zając, M., Tokarska-Guzik, B. (1998): Kenophytes in the flora of Poland: list, status and origin. - In: Faliński, J.B., Adamowski, W., Jackowiak, B. (eds.): Synanthropization of plant cover in new Polish research. Phytocoenosis 10 (N.S.), Supplementum Cartographiae Geobotanicae 9: 107-116. 